\title{
Biodiesel in Brazil: Agricultural R\&D at Petrobras Biocombustível
}

\author{
Renata Martins Sampaio ${ }^{1 *}$, Maria Beatriz Machado Bonacelli
}

\begin{abstract}
The expansion of the use of biofuels is based on the implementation of public policies to support production, technological development and the market. In Brazil, the National Program for the Production and Use of Biodiesel (PNPB) seeks to articulate these incentives and attract private initiative in promoting sustainable production. Investigating the business actions for the development of new technologies in the face of public stimulation motivates this article that aims to analyze the Research and Development (R\&D) strategies of Petrobras Biocombustível in the production of biodiesel. The case study is based on the theoretical arguments of the Entrepreneur State and on a case study accompanied by a qualitative analysis. The results indicate that the formation of agricultural research networks favored the construction of knowledge, research infrastructures and training of people, but did not innovated the production of biodiesel.
\end{abstract}

Keywords: Sustainability; Renewable Energy; Entrepreneurial State

Submitted: August 31 $1^{\text {st }}, 2017$ / Approved: April 19 $9^{\text {th }}, 2018$

\section{Introduction}

The large share of oil in the composition of the world energy matrix has encouraged discussions on several fronts. They bring together, in particular, the debate around themes such as energy security, pollution, increase of greenhouse gas emissions and global warming. Among the ways pointed out are the possibilities and challenges for the production and use of biofuels, ethanol and biodiesel, as alternatives for reducing the consumption of fuels derived from oil, gasoline and diesel.

In this debate are the discussions of Elliot (2000) that places biofuels as complementary or alternative to gasoline and diesel, and therefore immersed in the need for a large and continuous scale of production and the necessary construction and implementation of public incentives. Mowery et al. (2010), also highlight the role of the State in the construction of an environment favorable to the progress of biofuels, and emphasize fiscal and financial incentives as well as taxation of competing technologies and support for technological development as fundamental. In addition to the aspects related to market formation and new technologies. Is also considered the production of biofuels as an alternative for the development of agriculture through the production of raw materials. Similarly, Floray et al. (2012) shows that the use of new technologies, such as biofuels, requires an active state and capable of understanding its role in building spaces connected to the demands of society.

These collected evidences are present in the National Program for the Production and Use of Biodiesel (Programa Nacional de Produção e Uso de Biodiesel - PNPB), a public policy aimed at encouraging the sustainable production of biodiesel in Brazil that seeks to form a new market, through social inclusion and regional and technological development. This program, implemented in 2005, structured in fiscal and financial incentives, compulsory consumption and the Social Fuel Seal (Selo Combustível Social), an instrument that links the access of companies to incentives and the promotion of social inclusion and regional development.
The seal is granted to companies that buy raw materials from family farming present in certain regions of Brazil, especially the Northeast Region. This condition places the PNPB the challenge of the development of agricultural technologies in the production of oilseeds adapted to the characteristics of the familiar regional production. The architecture of the program and its objectives are the subject of debates that highlight the difficulties to be overcome, whether those evidencing the production reality of the Brazilian Northeast (Garcia, 2007) or those that expose the traps placed by the predominance of soybean in the production of biodiesel, strengthened by the limited technological knowledge of alternative raw materials (Abramovay \& Magalhães, 2007). Despite the criticisms, the PNPB has advanced and completed twelve years of existence, mobilizing various actions in the different social segments that it seeks to articulate. The most important segment is soybean agroindustry, which accounts for $70 \%$ of biodiesel production in Brazil. This mature and widely established agroindustry in Brazilian agriculture is capable of supplying the advance of biodiesel production, at the same time reducing the interest and risk of the technological development of aletrnativas raw materials.

The actions aimed at Brazilian biodiesel production involve the participation of Petrobras Biocombustível, a subsidiary of Petrobras S/A. The subsidiary's strategies are based on the construction of production infrastructure and, unlike the soybean industry, on research and development (R\&D). The effort in the search for the technological development involved the organization of the Research Networks in Oilseeds of Petrobras Biocombustível and mobilized 19 public agricultural research centers. Petrobras' differentiated and ariscated position - an innovative company in its main business, oil exploration and refining - motivates the issues that lead to this article. How were research networks organized and conducted? What developments can be identified?

(1) Instituto de Economia Agrícola (IEA), Agência Paulista de Tecnologia dos Agronegócios (APTA), Praça Ramos de Azevedo, 254, São Paulo-SP, Brasi (2) Departamento de Política Científica e Tecnológica (DPCT), Universidade Estadual de Campinas (UNICAMP), Rua João Pandiá Calógeras, 51, Campinas-SP, Brasil

${ }^{*}$ Corresponding author: renata@iea.sp.gov.br

ISSN: 0718-2724. (http://jotmi.org)

Journal of Technology Management \& Innovation @ Universidad Alberto Hurtado, Facultad de Economía y Negocios.

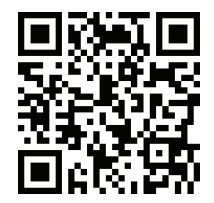

66 
The coping or incorporation of risks and uncertainties in the development of new technologies and new markets are elements that form an unattractive universe for companies. This instability has an important strategy in the formation of new businesses that characterize the new markets, such as renewable energy, such as the production of biodiesel in Brazil in the State of Entrepreneurship and its ability to reduce uncertainties (Mazzucato, 2014). Thus, the article is organized into four sections beyond this introductory one. The second section presents the contributions made by the Entrepreneurial State of Mazzucato (2014) and the structure of analysis composed by descriptive analysis and case study. Subsequently, the third section discusses the PNPB and its results. The fourth section discusses the elements present in the construction and results achieved with Petrobras R\&D strategy for biodiesel production. Finally, the final section deals with conclusions and final considerations.

\section{Entrepreneurial Status: the risk of technological development}

This section is organized in two subsections. The first subsection presents and discusses the arguments and concepts that structure the theoretical approach of the State Entrepreneur, highlighting the importance of public policies to boost the development of new technologies and new markets, such as biodiesel. In the sequence, the second subsection incorporates the elements of the theoretical discussion to the study methodology that articulates a qualitative descriptive analysis to the case study.

\subsection{New products and new markets}

The development of technologies in renewable energies is fundamental for the transformation of the current energy matrix rooted in the technologies of the fossil standard. The permanence in the fossil pattern excludes the chance of the society to promote a truly transforming space. This transformation requires technologies for recyclable materials, advanced techniques of waste management, improvement of agricultural practices, among other innovations. The starting point, the path to be followed and where the arrival will be are quite nebulous variables of this high risk process (Mazzucato, 2014).

The uncertainty and risk associated with these technologies is rooted in a diverse range of economic segments and in the deep domain of existing technologies. This environment marked by the necessary technological development places the State in the important role of formatting public policies with instruments that enable the execution of and R\&D projects and encourage production (Mowery et al., 2010; Olmos, et al., 2010).

For Mazzucato (2014) the role of the State lies in the articulation of the innovation process and also in entrepreneurial actions. The undertaking for the State is in the strategy of taking the risks of technological development and occupying a space of uncertainty that private initiative is not willing to face. This placement originates from arguments built from two fronts of discussion.

The first one is aligned with the concepts and arguments of the evolutionary economy, punctuated, among other evidences, by the competition marked by innovation in products and processes and the search for technological evolution from scientific, technical and tacit knowledge, institutions, processes and organizational forms. As well as machines, equipment and products. In this search, companies are placed as the prime responsibility for innovation, but they are accompanied by governments, research organizations, universities, public policies and other components that form the so-called systems of innovation with repercussions for the development of nations. As for competitiveness in markets, both in industry and agriculture (Dosi \& Nelson, 2009).

The second front of discussion deals with the role of the State in economic development and has in the critics of neoliberalism the references for the construction of the arguments that support the vision of Entrepreneurial State. For Mazzucato (2014), the discourse that the public sector is bureaucratic, incompetent, intrusive and intrusive and too big to be dynamic, as opposed to the dynamism, efficiency, entrepreneurship and innovative nature of the private sector, has built the idea that the state must basic services and correcting any market failures. In this vision, it would be up to the State to facilitate the process of innovation and to provide conditions for the private initiative, always available to take risks and invest in $\mathrm{R} \& \mathrm{D}$.

This way of interpreting reality has emptied the debate about the role of the state in development and has resulted in the shaping of public policies in innovation that built myths. The first of these lies in the direct causality between $R \& D$ and innovation - just invest in $R \& D$ to innovate - when in fact a series of complementary assets is needed for innovation to occur. The second myth is that smaller firms are more apt to innovate. The evidence shows that the size of companies does not always justify their growth but rather productivity. Another myth is that the number of patents reflects growth in terms of innovation, which in fact in certain markets is much more related to legislation and competitive strategies. Next, the myth that business investment needs fewer taxes and bureaucracy when evidence does not prove that $\mathrm{R} \& \mathrm{D}$ tax credits actually contribute to its development. In addition to these, the myth that venture capital "worships" risk, when in fact it escapes risk and only appears when uncertainties are smaller (Mazzucato, 2014).

Mazzucato (2014) points out that the risks and uncertainties associated with entrepreneurship and innovation linked to investments in $\mathrm{R} \& \mathrm{D}$ and technological change are not always absorbed by the private sector. This entrepreneurial role has in many cases been played by the state with its long-term investments in science and technologys ( $S \& \mathrm{~T})$ and $\mathrm{R} \mathrm{D}$, which are materialized in new products, new processes and new markets. The state assumes the risk of betting on fronts so unknown that even the uncertainties are identified, such as the development of the internet. Private initiative participates from the moment the risks and uncertainties of technological development can be identified. The author takes as an example the technologies touchscreen and GPS that gave support to the development and commercialization of iPhone and iPad and that are the result of many years of research financed by the State with the Department of Defense of the United States. 
In this sense, the arguments put forward put the State as an active participant in the process of technological development necessary for the adoption of new products and new processes and also for the creation of new markets. This construction has in the interaction between public and private action formatted in public policies the ways to reduce the risks and uncertainties tied to new markets and new technologies.

\subsection{Analysis structure}

The arguments of Mazzucatto (2014) emphasize the importance of state participation in technological development, in encouraging the formation of new markets. The public incentive to development is permeated by the view that the private initiative seeks to invest in businesses with risk and uncertainty foreseeable. These conditions are not always measurable in new technologies and markets. The difficulty of analyzing new investment scenarios for private enterprise is partly amortized by public action through policies and programs that support specific technologies and markets.

The formatting of structured public policies in support mechanisms and incentives to new technologies and markets is present in the architecture of the PNPB. Thus, the methodology adopted initially seeks to explore the instruments and results achieved with the PNPB, and then, to guide the case study and to identify how the private initiative has internalized the incentives and objectives of the program.

The descriptive analysis of the program was conducted from two stages of research. The first met and analyzed information contained in laws and decrees that regulate the activities and objectives of the PNPB. The second stage worked on statistical series and data on the dynamics of Brazilian biodiesel production from 2005 to 2016, made available by the Agência Nacional de Petróleo, Gás Natural e Biocombustíveis (ANP - National Agency of Petroleum, Natural Gas and Biofuels). The information collected and analyzed in the two stages of research were complemented with results of recent technical-scientific studies that dealt with the PNPB.

The results of the descriptive analysis of the PNPB helped in the case study that, among the different strategies to overshadow the incentives and risks of biodiesel production in Brazil, explored Petrobras Biocombustível's R\&D investment strategy, structured in Petrobras Biocombustível' Oilseeds Research Networks. In order to address this case study, in order to identify the company's strategies aimed at biodiesel production, the information provided by the company was gathered through its annual reports, considering the period from 2005 to 2016. The analysis is completed with the treatment of the development of technological development strategies, through interviews with researchers who coordinated research projects in two of the nine networks structured by Petrobras Biocombustível.

The two research networks selected were those dedicated to research with jatropha. The choice of these nets is due to the fact that jatropha is placed as a rustic oleaginous and placed as promising to be produced by family farming in the Northeast Region of Brazil. To apprehend this and previous investments in research, still lacking knowledge about its genetics and breeding, production, harvesting and processing techniques, according to Martins (2010). The interviews were conducted from November 2015 to March 2016, through a script with 12 open questions organized in two categories: network operation and results achieved. The interviewees lead studies carried out at the following public agricultural research centers: Universidade Estadual Paulista (UNESP) Campus de Ilha Solteira, Instituto Agronômico (IAC), Empresa de Pesquisa Agropecuária de Minas Gerais (EPAMIG) and Universidade Estadual de Campinas (UNICAMP), Laboratory of Biotechnology.

In the search to understand the unfolding of this initiative in $\mathrm{R} \& \mathrm{D}$ for the company, an interview was conducted through a virtual process during the month of April 2016 and a structured itinerary in 12 questions and three categories: network objectives, results achieved and future prospects. The interview was directed to the Agricultural Technology Management to the Petrobras Biocombustível.

\section{The production of biodiesel in Brazil}

The production of biodiesel in Brazil is linked to PNPB and Law $11,097 / 2005$, that inserted biodiesel into the Brazilian energy matrix by mixing diesel oil and biodiesel (BX). Started in 2005 with the optional blend of $2 \%$ (B2) of biodiesel to diesel, it reaches 2017 with a mandatory blend of $8 \%$ (B8) and projections to $9 \%$ and $10 \%$ by 2019 . The goal of the program is to implement production and the use of biodiesel in Brazil in a sustainable manner, promoting social inclusion, guaranteeing competitive prices, quality, supply and production from different sources of oilseeds in diverse regions. The actions have an interministerial structure, with emphasis on the Ministério de Minas e Energia (MME), Minstério de Desenvolvimento Agrário (MDA), currently transformed into the Secretaria Epecial da Agricultura Familiar e Desenvolvimento Agrário, Ministério da Ciência, Tecnologia e Inovação (MCTI), now Ministério da Ciência, Tecnologia, Inovação e Comunicação (MCTIC).

To achieve its objective, this public policy brings together various instruments and organizations that accommodate a set of incentives and rules for production, commercialization and support for technological development. In the promotion of production are the Programa de Financiamento a Investimentos no Biodiesel, conducted by the Banco Nacional de Desenvolvimento (BNDES) and tax incentives. The commercialization, in a regulated market, is supported by a system of auctions of purchases and quality control, with the participation of the ANP in the organization of the auctions and edition of the technical specifications, and of Petrobras in the control of stock executed through negotiations involving the Purchase of biodiesel in the ANP auctions and the transfer to the diesel distributors that serve the national diesel market.

The financial and tax incentives and the rules of the auctions are linked to the Social Fuel Seal, an identification component granted to the biodiesel producer who acquires a minimum percentage of raw material from family farmers included in the Programa Nacional de Fortalecimento da Agricultura Familiar (PRONAF), executed by the MDA. This instrument for the promotion of social inclusion and 
regional development, with emphasis on the Northeast Region and on the oil-producing area produced by family agriculture, castor bean, as Azevedo (2010) points out, was widely publicized in the media and its links and objectives built expectations in the solution of historical problems of this Brazilian region. The biodiesel producer that holds the seal is destined to participate in $80 \%$ of the auction volumes and special conditions in access to financing and tax incentives. In addition to these instruments, PNPB also incorporates support for technological development through the Rede Brasileira de Tecnologia de Biodiesel and the Câmara Setorial da Cadeia de Produtiva de Oleaginosas e Biodiesel, which brings together representatives of the various segments of the production chain and created Ministério de Agricultura, Pecuária e Abastecimento (MAPA).

The discussion between the proposed objectives the instruments and the results are based from the beginning of the PNPB in works such as de Abramovay \& Magalhães (2007) and Garcia (2007) who, as in García (2016), discuss the difficulties of implementing Development policies without understanding the local reality and joint mobilization of their assets. For example, the regional concentration of production, as in 2016, together, the Central-West and Southern regions of Brazil accounted for more than $80 \%$ of the national production, as opposed to the small Northeast Region (ANP, 2017). The regional distribution of production is based on regionalization of soybean production and processing, the main raw material for biodiesel production, responsible for more than $70 \%$ of the national production (ANP, 2017). This reality limited the effective participation of other oilseeds capable of promoting the regional distribution of production and the inclusion of family agriculture, especially the one that needs support to consolidate, according to Campos \& Carmélio (2009).

The debates about the regional distribution and its relations with the raw materials for biodiesel production intertwine with the questions about the participation of the biodiesel plants. The discussions involve the ample idle capacity and its unfolding for the market and the investments with public resources that were made (Mendes \& Costa, 2010). Also, the participation of companies originally associated with the production and processing of soybeans is highlighted, with biodiesel being another business option, as a counterpoint to the formation of new enterprises for a new market (Sampaio \& Bonacelli, 2015).

The results built in front of the proposed objectives open space for questions about the scope of institutional arrangements formatted in the PNPB and its limitations to promote development in interaction with private initiative and connected to the needs of society (Pedroti, 2013). This discussion is reinforced when the evolution of the production is observed, accompanying the increase of the mixing percentages and the consumption of diesel. Brazilian biodiesel production jumps from $750 \mathrm{~m} 3$ in 2005 to 3.8 million $\mathrm{m} 3$ in 2016. According to the ANP (2017), in the period from 2013 to 2016, Petrobras Biocombustível accounted for $10 \%$ to $15 \%$ of annual production, among the main biodiesel producing companies in Brazil.

In this sense, we have the success of PNPB in the proposal to include biodiesel in the Brazilian energy matrix. But, also, the realization that this capacity did not extend to the promotion of the innovations necessary to reach its objectives of social inclusion and regional development, especially of the Northeast Region of Brazil. These results indicate that the implementation of $\mathrm{R} \& \mathrm{D}$ actions and the construction of technologies, mainly in the production of raw materials, are fundamental for a scenario of enormous technological challenges and restricted indications of the paths to be followed. In this way, the experience of Petrobras Biocombustível, based on investments in R\&D, positions itself as a strategy that seeks to break this obstacle built from the PNPB.

\section{Agricultural R\&D at Petrobras Biocombustível}

The implementation of the PNPB and its development, as elaborated in the previous section, built a scenario based on the need for agricultural technological development in oilseeds or raw materials alternative to soy, in order to achieve the objectives of social inclusion and regional development. Under these circumstances, Petrobras Biocombustível created $R \& D$ initiatives. To present and discuss the results achieved, this section was structured in two subsections. The first deals briefly with Petrobras' move towards renewable energy and the production of biofuels, especially biodiesel. The second subsection analyzes investments in R \& D in oilseed production, observing the actions directed to research with jatropha.

\subsection{The Petrobras Biocombustível}

The history of one of the main Brazilian companies is permeated by economic aspects inherent in the main market in which it operates - the oil market. But, also, for political and driving issues of the Brazilian economy that influence the choices and paths traced by Petrobras over more than 60 years. The creation of Petrobras takes place amidst polarized discussions that addressed, in particular, the issue of the monopoly on oil. At that time, the private initiatives in the construction and operation of refineries were being absorbed by the state as its knowledge was improved in a broad process of learning from oil exploration to refining and distribution of derivatives. The capacity developed by the company has been expanded with emphasis on investments in oil prospecting and exploration in offshore fields. This strategy expanded the company's oil production capacity and established a broad investment program in $\mathrm{S} \& \mathrm{~T}$ and $\mathrm{R} \& \mathrm{D}$, organized in partnership networks with universities, research institutions and supplier companies.

In the last years the movement of Petrobras involves the generation of electricity, discussions and worldwide actions around sustainable development, biofuels and several other applications for biomass. In this context, the Petrobras System is consolidated with new subsidiaries and expansion of activities, with the production of ethanol, sugar, bioelectricity and biodiesel. In the same period, Brazil achieves selfsufficiency in oil production and Petrobras becomes a signatory of the ONU Global Pacto and announces the discovery of the new oil reserves - Pré-Sal.

The expansion of Petrobras' activities from biofuels can also be seen in other oil companies operating in Brazil. It highlights the partner- 
ship between Shell and the Grupo Cosan, creating Raízen, which produces and markets sugar, ethanol and bioelectricity. The same strategy is carried out by BP Brasil with the participation in Tropical Bioenergy. Also, it is worth highlighting the Brazilian euphoria with the possibility of the country assuming a prominent position in the world production of biofuels.

These conditions are important in the construction of the creation strategies in 2008 of Petrobras Biocombustível, which brings together Petrobras' activities related to the production and commercialization of ethanol and biodiesel. Particularly for biodiesel, the company's operations began in 2006 with the installation of an experimental plant in the Northeast region of Brazil for the production of biodiesel, associated to the intensification of $\mathrm{R} \& \mathrm{D}$ activities related to the production of biofuels and other applications, for example Biolubricants and the interactions between biomass and petroleum products (Petrobras, 2005).

The creation of Petrobras Biocombustivel brought together actions aimed at the construction of three biodiesel production plants. A located in Candeias, Bahia, where Petrobras operates the production terminal for the Refinaria Mataripe. The second plant located in Montes Claros, Minas Gerais, and the third in Quixadá, Ceará (Petrobras, 2006). The biodiesel production infrastructure was reinforced with the acquisition of $50 \%$ of the BSBios plant located in Marialva, Paraná. As well as $50 \%$ of the shares of BSBios Indústria e Comércio de Biodiesel Sul Brasil, Passo Fundo plant in Rio Grande do Sul and 50\% of Bioóleo Industrial e Comercial SA, located in Feira de Santana, Bahia, by crushing oilseeds (Petróleo, 2010).

This move of the company established the production structure for biodiesel, from three own plants located in the Northeastern Region and the semi-arid region of Brazil, in addition to two plants operated in partnership in the South Region. Petrobras Biocombustível also organized two clearly integrated strategies associated with instruments formatted in PNPB and its objectives of social inclusion and regional development. One of them, the o Programa de Apoio à Produção de Oleaginosas pela Agricultura Familiar and the Redes de Pesquisa em Oleaginosas da Petrobras Biocombustível, focus on this article and work on the next subsection.

\subsection{The Redes de Pesquisa em Oleaginosas da Petrobras Biocombustível}

In order to work on the strategy of creating the research networks of Petrobras Biocombustível, it is important to retrieve elements that deal with the management model of Petrobras R\&D activities and the financing sources provided for in legislation. Since 2006, Petrobras' R\&D management model has been organized in 49 thematic networks distributed in the following topics: 14 in oil and gas production, 13 in refining and petrochemicals, 6 in oil and gas exploration,
5 in materials, 4 In environment, 3 gas and energy, 2 for advanced computing. And an for technological management and another that opens up research on bioproducts.

In the bioproducts research network, technologies are being developed in evaluation of glycerine injection for advanced oil recovery and tests for the production of second generation ethanol from sugarcane bagasse. Also in evaluation of new methodologies for emissions measurement and evaluation of the potential of different types of vegetation in $\mathrm{CO}_{2}$ sequestration. The research network on bioproducts also aggregates studies for the production of microalgae in hypersaline waters, production of lubricant from castor biodiesel (biofuel), production of polystyrene from soybean oil, production of gasoline and diesel oil from of bio-oil of wood. Biodiesel production with tilapia oil, produced from the viscera and mixed with $10 \%$ of bovine tallow (Tecnologia Petrobras, 2011, 2012, 2013). In addition, this research group is also part of the activities of the network in bioproducts the research areas of the Redes de Pesquisa em Oleaginosas da Petrobras Biocombustível

Redes de Pesquisa em Oleaginosas da Petrobras Biocombustível were established in 2010 through agreements signed by the Centro de Pesquisa da Petrobras (CENPES), which applies financial resources and accompanies the execution of research projects, including subsidies such as Petrobras Biocombustível. Prior to the creation of Petrobras Biocombustível, there were already research projects with oleaginous plants in progress that were integrated into the Networks. These projects are those linked to agreements with public agricultural research centers, allocated to networks 6,8 and 9 , as shown in Table 1 . The other research projects were signed as of 2010, except for the Jatropha Network, object of this study, which was started in 2009.

According to information gathered from the interviews, the selection of related oilseeds followed different criteria. For castor beans the justifications were the existence of a defined production system, the Semiárido region and family farming as a traditional producer. The sunflower for having the potential to adapt to the crop in the Northeast, but dependent on technical-scientific knowledge for its production. The palm, traditional culture, cultivated in Pará and Southeast of the State of Bahia, with a system of cultivation suitable for both large extensions and family farming. For Jatropha, expectations about this little-known "new oilseeds", but with national and international research, were promising for production by the family farming of the Northeast. The macaúba, also a "new oilseeds", the rusticity and being a native plant in Brazil present in several biomes, offered the contours for its inclusion in the research networks. In addition to these oleaginous crops, other crops were also investigated prior to the formation of nets, such as soybean and canola, and prospectively the tucumã, inajá and faveleira. 
Quadro 1 Redes de Pesquisa em Oleaginosas da Petrobras Biocombustível

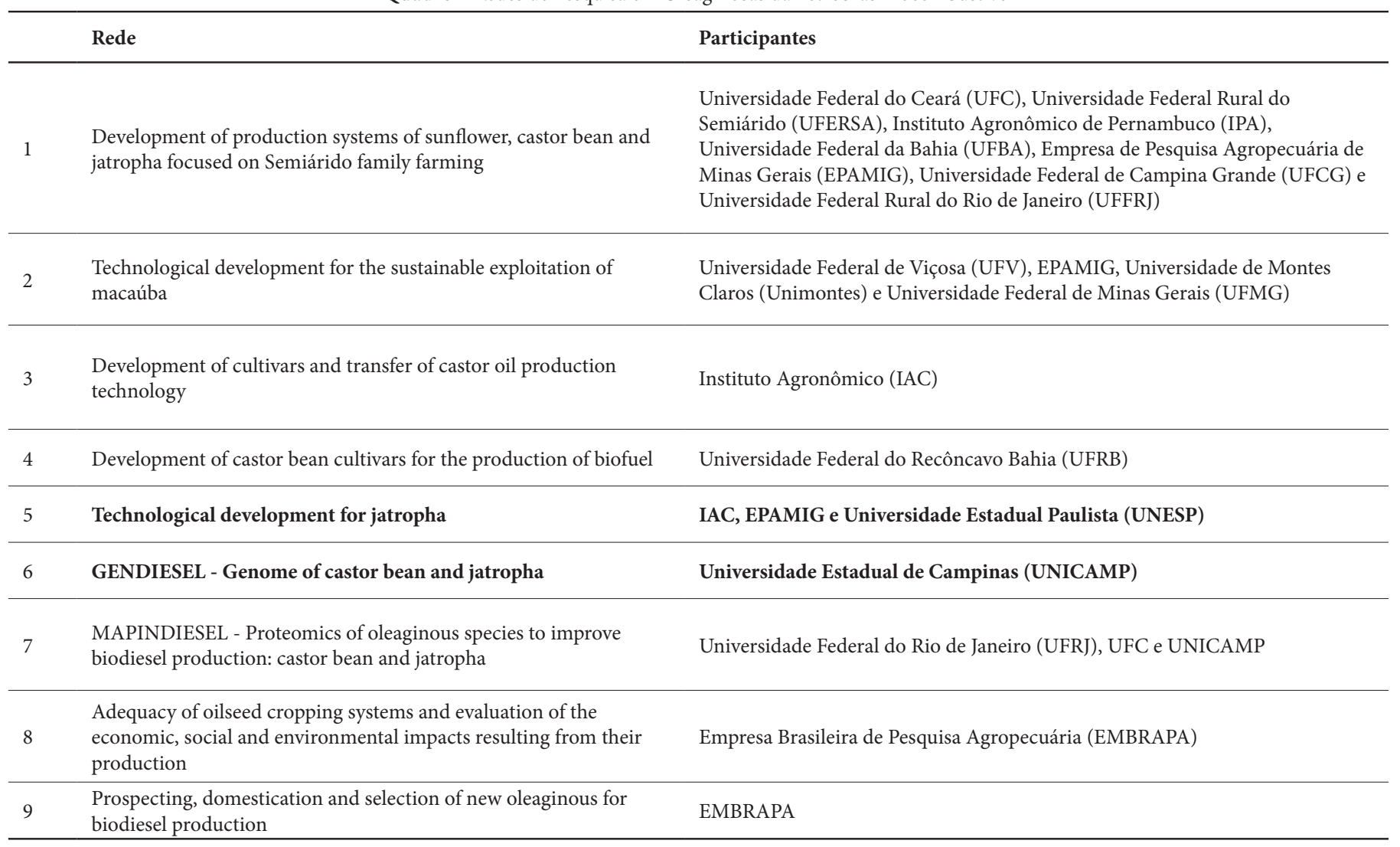

Fonte: Gonçalves (2011)

The results of the interviews indicate that, on the side of those who accessed the financial resources destined to network 5 "Technological development for jatropha", the contact with Petrobras occurred in a personal way, through relations between researchers who already developed researches with jatropha before the formation of the networks, and those responsible for the strategy with CENPES. In this process, the interested researchers and the related research organizations started the registration procedures with the ANP, a legally required step for any research project, as well as completing the forms and gathering the necessary documents to submit the research proposal Petrobras' evaluation criteria.

After several adjustments, UNESP became the coordinator of the network, which hosted three projects: Basic and applied technology development for jatropha, executed by UNESP, Biotechnologies suitable for the genetic improvement of jatropha in order to obtain interspecific hybrids, under the control of the IAC, and jatropha as an alternative of raw material for the production of biofuels, linked to EPAMIG.

During the execution of the research projects, from 2009 to 2015, meetings were held with CENPES to present the results achieved and discuss the steps to be taken. Likewise, the CENPES team also visited the research centers to follow up the activities and the experiments carried out. In this process, the EPAMIG project was disconnected from the jatropha network and financial resources were allocated to the IAC project. In addition to face-to-face control, there was the preparation of activity and financial reports related to the application of resources, as well as the control of publications and dissemination of the results achieved with the projects.

In the investigation of the contribution achieved with the projects, the interviews allow to highlight the advances in the knowledge of the jatropha culture. At present, it is a consensus that the expected rusticity has not been confirmed, that there is potential for more than one crop per year and that the production of jatropha consorted with other crops is shown as a feasible and necessary way for the viability of the crop as an alternative Family farming. From the point of view of the genetic knowledge of the plant, the project allowed the increase of the germplasm bank with non-toxic materials, important in the use of oil byproducts, protein-rich bran, also the selection of small specimens, fusário tolerant, uniformity of maturation and conformation of the productive cycle.

The researchers also highlighted the training of human resources, including foreigners. There were more than twenty research grants for students of scientific initiation, masters and doctors, as well as several publications, theses and dissertations with culture as focus. Likewise, the partnership with other research centers, especially in Mexico. Also, it is worth mentioning the development of research based on the results achieved with the GENDIESEL project and the partnership with 
researchers from the Oswaldo Cruz Foundation (FIOCRUZ). Another result mentioned was the improvement of the research infrastructure, through the acquisition of equipment, construction and adaptation of the facilities. In this regard, in particular at UNESP, laboratories and a pilot plant for the production of biodiesel were created and equipped, thus creating a favorable environment for new research to be carried out, as well as the formation of the largest experimental field of jatropha. Likewise, the accreditation of research centers is seen as an important element for new opportunities with Petrobras.

The information gathered from the interview with gerencia de tecnologia agrícola by Petrobras Biocombustível indicates that the expected results with the networks have been achieved, but each agreement and project has its particularities. The practical or strategic knowledge was applied to the operations with the Programa de Apoio à Produção de Oleaginosas pela Agricultura Familiar. But, the results in basic research still require further efforts to be applied. When considering the operation of the networks as a whole, it was observed that there are more collaborative institutions and others less. Such as the macaúba research network, in which the works were carried out in an integrated way with good results, different from the network of "Development of systems ", which had a large number of research institutions, but with difficulties in its management.

Considering the results achieved for jatropha, a perennial crop, the continuity of support for research projects is pointed out as fundamental for this raw material to effectively contribute to the production of biodiesel. This action by Petrobras Biocombustível was expected by the project coordinators. But, during the interviews it was pointed out that from 2012 there was a certain weakening of the actions gathered in the networks and the vision of closing the activities was present. Despite the discontinuity and interruption of the research, it was indicated that without the support of Petrobras Biocombustível, the research carried. This not only for the resources invested, but also for the important actions in the articulation of the research centers for the construction of new paths for the technological development of raw materials for biodiesel production in Brazil. As pointed out by Scoponi (2016), the articulation and cooperation among research institutions is fundamental for boosting agricultural innovation, constituting established and long-lasting research networks.

At Petrobras Biocombustivel the research networks were finalized and the orientation is to discontinue the development of oilseed research for biofuels. At the time of the debutant, there was no prospect of resuming activities. It was commented, however, that the lessons learned in the period from 2008 to 2016 are being considered. That the company will continue to work, through its mills, in the promotion of the acquisition of raw materials from family farming aimed at participation in the purchase auctions of Biodiesel promoted by the ANP, with no plans to implement new projects.

On the other hand, the research institutions that participated in the jatropha network seek two paths. The first one related to the continuity of the researches and maintenance of the experiments with the objective of avoiding losses, through new research projects submitted to the de- velopment agencies, for example, the Fundação de Amparo à Pesquisa do Estado de São Paulo (FAPESP) and others sources, in a strategy with no prospect of relying on the private initiative. The second path identified was the abandonment of research with jatropha and the directing of efforts to other crops, in the face of the disillusionment with the possibilities of jatropha participation in the production of biofuels

Petrobras Biocombustível also invested in other fronts, such as the use of geoprocessing as a tool to support the management of the application of resources in areas with greater productive potential. In 2012, the company systematized its safety, environmental and health processes and created the Corporate Waste Management Plan. In 2013 and 2014, in partnership with Embrapa, it implemented twelve Unidade de Teste e Demonstração (UTDs) with castor bean in the Semiárido region, as well as researches on fish oil, algae and macaúba, as commented above. In 2015, it completed and implemented the Geographic Information System, which allows, through the Internet, geographic, environmental and agricultural performance analyzes, providing detailed information that improves management.

\section{Conclusions}

The search for new paths in energy generation highlights the production of biofuels and the need to format public policies. These public action instruments seek to encourage the formation of new markets and the development of these new technologies. In Brazil, the PNPB is an example of these initiatives that are based on the sustainable production of biodiesel, through economic viability, social inclusion and regional development. This program is structured on fiscal, financial and technological incentives that mitigate the risks of a new market and attract private initiative in the construction of strategies. Among the companies participating in the PNPB, the soybean agroindustry, the main raw material used, and Petrobras Biocombustível stand out.

The company, a subsidiary of the oil company Petrobras, structured strategies that involved broad support for R\&D activities, aiming at the development of alternative raw materials for soybeans, gathered in Petrobras Biocombustível Oilseed Research Networks, which is the object of the study. The arguments of the Entrepreneur State that highlight the importance of the State in the development of new markets and new technologies led to a descriptive research and case study to investigate the training, conduction and results achieved with the Networks.

The results show the interest of Petrobras, an innovative company of international renown, in the development of research involving biomass in its various applications, including biofuels. For biodiesel, the company structured production and $\mathrm{R} \& \mathrm{D}$ strategies with a view to aligning PNPB instruments with their objectives. Experience with agricultural research and its public centers has resulted in important advances in knowledge with oilseeds, especially jatropha, building infrastructure and training of people, as well as the difficulties to continue the work in the face of the closing of investments. The results also show the fragility of the relationship between the research centers and the company. Exposes the company's distance from the timid application of the knowledge achieved and thus, highlight the discussions about R\&D 
risks and private initiative in the production of Called the background research, to the same extent that it highlights the limits of the PNPB in involving companies in the development of new technologies.

\section{References}

Abramovay, R., \& Magalhães, R. (2007). O acesso dos agricultores familiares aos mercados de biodiesel: parcerias entre grandes empresas e movimentos sociais. Texto para Discussão, Fundação Instituto de Pesquisas Econômicas (FIPE), São Paulo, SP, junho, n. 06, 36 p.

ANP. Agência Nacional do Petróleo, Gás Natural e Biocombustíveis (2017). Anuário e Dados Estatísticos, Produção de Biodiesel. Available: http://www.anp.gov.br/?pg=69299\& $m=\triangleleft t 1=\triangleleft t 2=\& t 3=\& t 4=\& a r$ $=$ é $p s=$ ¿ 1460747723376 .

Azevedo, A.M.M. (2010) Análise Top-down e Bottom-up de um programa de inovação energética: o Programa Nacional de produção e uso de biodiesel (PNPB). Tese de Doutorado. Instituto de Geociências. Universidade Estadual de Campinas (UNICAMP), Campinas -SP, 254 p.

Campos, A. A,. \& Carmélio, E. C. (2009). Construir a diversidade da matriz energética: o biodiesel no Brasil. In: Abramovay, R. (org.). Biocombustíveis: a energia da controvérsia, 59 - 97.

Dosi, G,. \& Nelson, R.R. (2009). Technical Change and Industrial Dynamics as Evolutionary Processes. Laboratory of Economics and Management, Sant'Anna School of Advanced Studies, LEM Working Paper Series, august, $89 \mathrm{p}$.

Elliott, D. (2000). Renewable energy and sustainable futures. Futures, 32, 261-274. doi:10.1016/s0016-3287(99)00096-8

Foray, D., Mowery, D.C., \& Nelson, R.R. (2012). Public R\&D and Social Challenges: What Lessons form Mission R\&D Programs? Research Policy, 41, (10), 1697-702. doi:10.1016/j.respol.2012.07.011.

Garcia, J. R. (2007). O Programa Nacional de Produção e Uso de Biodiesel e a Agricultura Familiar na Região Nordeste. Dissertação de Mestrado, Instituto de Economia, Universidade Estadual de Campinas, 200 p.

García, E.M.I. (2016). Economía Social + Innovación Tecnológica: experiencias de éxito em entornos de precariedad. Journal Technology Management \& Innovation, 11, (1), 86-92. doi:10.4067/S0718-2724206000100012.

Gonçalves, G. M. (2011). O Papel da Petrobras Biocombustível no Futuro da Agroenergia. Quais as Perspectivas. In: Congresso Brasileiro de Melhoramento de Plantas ... Anais $6^{\circ} C B M P$, Búzios, RJ, agosto.

Martins, R. (2010). Biodiesel de Pinhão-manso? Os Instrumentos Brasileiros de Apoio à Inovação Tecnológica para os Biocombustíveis. Dissertação de Mestrado em Energia, Universidade Federal do ABC, Santo André - SP, 197 p.

Mazzucato, M. (2014). O Estado Empreendedor: desmascarando o mito do setor público vs. setor privado. São Paulo, Portfolio-Penguin, 314p.
Mendes, A.P.A., \& Costa, R.C (2010). Mercado brasileiro de biodiesel e perspectivas futuras. Biocombustíveis, BNDES Setorial, n. 31, 253-280.

Mowery, D. C., Nelson, R.R., \& Martin, B.R. (2010). Technology policy and global warming: Why new policy models are needed (or why putting new wine in old bottles won't work). Research Policy, 39, 1011-1023. doi:10.1016/j.respol.2010.05.008.

Olmos, L., Ruester, S., \& Liong, S.-J. (2012). On the selection of financing instruments to push the development of new technologies: Application to clean energy technologies, Energy Policy, 43, 252-266. Doi:10.1016/j.enpol.2012.01.001

Pedroti, P. M. (2013). Os Desafios do Desenvolvimento e da Inclusão Social: o caso do arranjo político-institucional do Programa Nacional de Produção e Uso de Biodiesel. Instituto de Pesquisa Econômica Aplicada (IPEA), Texto para Discussão, n. 1858, 63p.

Petrobras, Petróleo Brasileiro S.A. (2005). Relatório Anual, Rio de Janeiro, RJ, 65 p. Available: http://www.investidorpetrobras.com.br/pt/node/559.

Petrobras, Petróleo Brasileiro S.A. (2006). Relatório Anual, Rio de Janeiro, RJ, 115 p. Available: http://www.investidorpetrobras.com.br/pt/node/550.

Petrobras, Petróleo Brasileiro S.A. (2010). Relatório de Sustentabilidade, Rio de Janeiro, RJ, 193 p. Available: http://www.investidorpetrobras.com.br/pt/node/1220

Petrobras, Petróleo Brasileiro S.A. (2016) Relatório de Sustentabilidade, Rio de Janeiro, RJ, 85 p. Available: http://www.investidorpetrobras. com. br/pt/node/1218

Sampaio, R. M., \& Bonacelli, M. B. M. (2015). Energia, Tecnologia e Instituições: a produção de biodiesel no Brasil. In: Congresso LatinoIberoamericano de Gestão da Tecnologia ... Anais XVI ALTEC, Porto Alegre, RS, 19 a 22 de outubro.

Scoponi, L., Fernandes Pacheco Dia, M., Pesce, G., Schmidt, M. A., \& Gzain, M. (2016). Cooperación Académica en Latinoamérica para la Innovación en los Agronegocios. Journal Technology Management \& Innovation, 11 (2), p. 111-120. doi:10.4067/s0718-27242016000200011.

Tecnologia Petrobras, (2011). Relatório Anual de Tecnologia da Petrobras. Centro de Pesquisa e Desenvolvimento da Petrobras (CENPES), 76 p. Available.: http://www.petrobras.com.br/pt/nossas-atividades/ tecnologia-e-inovacao/relatorio-de-tecnologia/.

Tecnologia Petrobras, (2012). Relatório Anual de Tecnologia da Petrobras. Centro de Pesquisa e Desenvolvimento da Petrobras (CENPES), 72 p. Available: http://www.petrobras.com.br/pt/nossas-atividades/ tecnologia-e-inovacao/relatorio-de-tecnologial

Tecnologia Petrobras (2013). Relatório Anual de Tecnologia da Petrobras. Centro de Pesquisa e Desenvolvimento da Petrobras (CENPES), 78 p. Available: http://www.petrobras.com.br/pt/nossas-atividades/ tecnologia-e-inovacao/relatorio-de-tecnologial 
